\title{
DO SIMPLES AO DUPLO: UM ESTUDO DA OBRA DE OSWALDO FRANÇA JÚNIOR
}

Ângela Maria Salgueiro Marques*

RESUMO:

\begin{abstract}
Análise de três contos de Oswaldo França Júnior que sugerem ser a gênese elou sintese de alguns de seus romances. Nosso objetivo é verificar de que forma esses gêneros literários, explorados pelo autor, se apresentam como uma dupla matriz, visando à contínua técnica da reescrita.

PALAVRAS-CHAVE: Oswaldo França Júnior, contos, romances, duplo, reescrita.
\end{abstract}

0 mineiro 0swaldo França Júnior, falecido em 1989, aos 53 anos de idade, deixou-nos um conjunto de obras composto de treze romances e apenas um livro de contos, nos quais pode-se observar uma questão instigante: pensar em alguns contos, ou melhor, minicontos, como uma gênese e/ou síntese de alguns de seus romances. Não todos, evidentemente, mas alguns contos dão a nítida impressão de ser a matriz de determinados romances.

Para esse ensaio, foram selecionados três romances que se situam representativamente ao longo das publicações efetivadas pelo autor: 0 viúvo (1965), seu primeiro romance; Os dois irmãos (1976), e sua última obra publicada em vida, No fundo das águas (1987). Tal escolha se deve à possibilidade talvez de mapear alguns temas cuja repetição possa ser analisada em termos de conteúdo e de forma: um conto que se transforma em "duplo" de um romance ou um romance que parece estar condensado em conto; irmãos que se tornam tema principal em romance, como em Os dois irmãos, ou que aparecem sob a forma de personagens secundários em tantas outras narrativas. Um fato curioso é que a presença de os dois irmãos exemplifica não só

| Doutora em Letras: Poéticas da Modernidade (Área de concentração: Literatura Comparada), 2004. 


\section{EMTESE}

Belo Horizonte, v. 9, p. I-28I, dez. 2005

o tema já evidente no título da obra, bem como a estratégica posição que o romance ocupa no conjunto de suas narrativas, ou seja, ele se encontra exatamente no meio de todas as obras do autor publicadas em vida.

\section{"A REPRESA" \& NO FUNDO DAS ÁGUAS}

Um conto que sugere ser a gênese do romance No fundo das águas parece ser "A represa". Nele, um grupo de homens escolheu um lugar para viver, limitado por duas serras. Tudo deu certo até o dia em que as chuvas começaram, ameaçando destruir tudo o que construíram. Essa constatação já sinaliza uma indicação temática relacionada às enchentes que será abordada nessas duas narrativas e que, por sua vez, evoca o mito do dilúvio bíblico.

Nesse conto, observa-se o poder da natureza, exemplificado pela força das águas da chuva. Ainda que a intenção desses homens fosse a melhor possível, aí destacando-se a possibilidade de manutenção de uma beleza natural daquele vale verde, era inadmissível não se levar em conta o poder das águas da chuva que irrompem sobre a cidade e tudo é destruído. Entretanto, a falta de consciência sobre o inútil trabalho coletivo de empilhamento das pedras, para a construção da represa, não deve ser creditada a todos os homens da cidade, pois isso se deve apenas a um desses homens.

0 romance No fundo das águas começa com a represa já pronta, conforme se verifica com o seguinte trecho: "Quando as comportas da represa foram fechadas, todos já haviam abandonado as casas e as terras. Abandonado para nunca mais voltar. Tudo estava previsto e as águas subiram lentamente, alcançando primeiro a rua junto à margem do rio" (França Júnior, 1987: 7). A partir daí, o narrador, em terceira pessoa, vai narrando a vida de todas as pessoas que habitavam a antiga cidade que dorme sob a imensa represa. As águas vão cobrindo lentamente as ruas mais próximas à margem do rio, até atingir os pontos mais altos da cidade. Todas as personagens têm nomes, o que imprime um caráter de verossimilhança ao relato sobre os cidadãos 
que foram lesados pela decisão alheia aos interesses da comunidade. A ênfase recai então sobre a vida das pessoas que, de uma hora para a outra, têm de abandonar suas casas, sua história, enfim, tudo que thes conferia sentido à existência. Ao passo que, no conto, o foco principal é o espaço físico, e também a teimosia do homem para conter os "avanços" da natureza.

Chama a atenção do leitor a técnica narrativa desse romance: da mesma forma que as lembranças são reavivadas pela voz do narrador, as águas parecem vir subindo, juntamente com as lembranças. Assim, o que ocorre, é uma "subida" simultânea de águas e lembranças. Após cada relato sobre uma família, o narrador cuida para que - leitor não se esqueça de que as águas continuam a subir, e para que elas exerçam uma dupla função: fazer emergir as lembranças e, ao mesmo tempo, mantê-las submersas. Tanto é que o narrador passa a narrar a história de outras famílias, assim que as águas cobrem as casas dos moradores cuja história acaba de relatar. E assim, sucessivamente.

As palavras quase bíblicas "mas as águas vieram e cobriram tudo" são várias vezes repetidas, desempenhando o papel de um refrão que contribui para marcar um ponto-limite entre os dois níveis da narrativa, na medida em que conjuga critérios geográficos e topográficos, juntamente com níveis temporais relacionados com o papel da anamnese presente nos fios da memória desse narrador.

0 que está exposto acima nos remete ao mito do dilúvio que não só faz parte da tradição cristã, contida no livro do Genesis, como também de outras culturas tais como a babilônica, a assíria e as indígenas. Embora varie nos detalhes, o mito do dilúvio nos apresenta um caráter duplo: tanto traz a idéia de castigo que merece a punição mais drástica, a destruição completa, quanto a de recriação, de regeneração, de renovação constante.

Convém lembrar que a idéia para a construção desse romance surgiu durante uma pescaria e de uma conversa do autor com um barqueiro, de acordo com o texto publicado na orelha da primeira edição. Seguindo a mesma estrutura narrativa do relato desse barqueiro, Oswaldo França Júnior escreve esse livro que fala sobre uma região que seria inundada pelas águas de uma represa. Podemos observar, então, que a repetição se dá em vários níveis: o reconto de uma história ouvida de um 


\section{EMTESE}

Belo Horizonte, v. 9, p. I-28I, dez. 2005

barqueiro, o desenvolvimento da idéia presente no conto "A represa" e a técnica narrativa que se repete inspirada no romance Aqui e em outros lugares (1984) o qual, diferentemente, apresenta personagens anônimas.

\section{“MEU IRMÃO” \& OS DOIS IRMÃOS}

"Meu irmão", conto que encerra uma semelhança muito acentuada com o romance 0 s dois irmãos, apresenta a questão da incomunicabilidade como o núcleo do que se vê ampliado no romance. Além de várias semelhanças entre os dois, convém esclarecer que, no conto, é o irmão que visita o narrador, ao passo que no romance é "o homem", personagem assim nomeado, que vai ao encontro do irmão e com quem o leitor parece compartilhar o ponto de vista.

No conto, ao se referir ao irmão, o narrador emprega duas vezes a palavra amargura: "A expressão era de amargura e suas lágrimas me queimaram." E: "As lágrimas secaram, sua expressão, no entanto, permaneceu retratando a amargura interna" (França Júnior, 1985: 22-23). A expressão de amargura revela todo o padecimento moral, a aflição e a angústia do irmão por não saber extravasar aquilo que o magoa. Apesar dos esforços envidados pelo narrador para secar as lágrimas do irmão, permanece a amargura interna, pois ele não consegue descobrir a causa desse desgosto arraigado de dor e ressentimento, dessa tristeza sem fim. 0 silêncio do homem contribuiu para que o irmão esquecesse o modo de pronunciar as palavras, o que acentua a questão da incomunicabilidade entre os irmãos, já tão difícil por causa da diferença entre os dois mundos nos quais cada um vive.

Essa diferença aponta para a questão do estrangeiro, aquele que vem "de fora", com uma outra cultura e que se sente perplexo diante do outro e de uma língua que não domina. 0 estrangeiro também é visto como um rival potencial e, embora se beneficie das leis da hospitalidade, ele pode se apresentar tanto como um "mensageiro de Deus" quanto uma "encarnação diabólica". Dessa forma, na primeira hipótese, deve-se honrá-1o e, na segunda, convém buscar a reconciliação com ele (Chevalier; Gheerbrant, 1989:404). Evidencia-se, aqui, o caráter dúbio da figura do estrangeiro. 
Embora o irmão não se apresente, no conto, como um imigrante em sua acepção mais usual, ele acaba se comportando como tal, já que vem de fora e "não sabia a língua nem os costumes" da terra do irmão. E, para complicar ainda mais a situação embaraçosa das relações com o irmão e com sua família, ele "havia se esquecido de como se pronunciam as palavras", por causa do "tempo em que permanecera em silêncio". Para estabelecer novos vínculos com esse outro ser, que ao mesmo tempo nos incita e ameaça, é impossível permanecer em silêncio. Mesmo que o outro não pudesse dizer as palavras e lançasse mão de algum outro modo de linguagem não-verbal, um mínimo de comunicação poderia existir. Pois, segundo Maria Rita Kehl, "[s]e o contato com o outro não passa pela reflexão, pela simbolização do outro, há de ser sempre um contato ameaçador e violento" (2000: 144).

Em Os dois irmãos, Oswaldo França Júnior explora o conflito entre duas personagens centrais que se chamam simplesmente o homem e o irmão. A tentativa do homem para convencer o irmão a voltar à "realidade" da vida, a se preocupar com as necessidades mais prementes de sua família é o fio condutor da narrativa. Em cada visita ao irmão, o homem se depara com um mundo completamente diverso do seu: o irmão não ouve seus conselhos, ao passo que dá a maior atenção às estórias doidas dos doidos. A técnica de reduplicação através da presença do espelho, mise-en-abyme (Dallënbach, 1977), é bastante explorada pelo narrador, pois as várias estórias contadas por outras personagens secundárias se encaixam na narrativa principal e permitem ao homem adentrar nesse mundo insólito do irmão. Mas o homem desabafa com a mulher: "Com muitos ele conversa. Com muitos ele troca idéias. Mas comigo ele quase não fala. Ouve coisas sem sentido dos outros e não escuta o que eu digo" (França Júnior, 1976: 27). Essas "coisas sem sentido dos outros", as micro-histórias da maioria das personagens que fazem parte da vida do irmão, é que vão entremeando a narrativa, destacando-se os comentários que não se tornam plausíveis através do diálogo com o irmão. Nesse sentido, a presença dos irmãos (não mais como gêmeos), vem confirmar uma questão recorrente na obra de 0swaldo França Júnior, ou seja, o motivo do duplo, e que já se mostra presente em seu romance de estréia, 0 viúvo. 


\section{EMTESE}

Belo Horizonte, v. 9, p. I-28I, dez. 2005

Outra característica já mencionada pela Profa Melânia Aguiar é "a mudança de linguagem, mais bíblica e metafórica que marcou o lançamento de Os dois irmãos, em comparação com os romances anteriores" (Aguiar, 1976: 2). Desse modo, o romance se assemelha a uma parábola sobre dois homens: um realista e outro sonhador, um homem comum e um quixotesco. Tais características conferem a ambos uma idéia de desafio, pois um dos dois acaba se posicionando como o adversário do outro, o que já revela mais um aspecto do motivo do duplo. Isso denota uma ressonância trágica, pois o duplo é freqüentemente índice de desarmonia. E o que predomina sempre nessa narrativa é a diferença entre os dois irmãos.

Esse indice de desarmonia pode ser melhor explicado pela perplexidade sombria com que nos deparamos ao longo da leitura de Os dois irmãos. Ela aponta para a conflitiva construção de uma identidade que é impossível de ser representada desconectada desse outro, o qual, por sua vez, nunca dá pistas fáceis para um possível entendimento. Por causa desse desencontro, uma sensação de desconforto aflora ao final da narrativa, uma vez que ela finaliza com um ponto de interrogação. Assim, temos um enigma insolúvel, pois em sua última visita, ao voltar para casa, "vindo da encosta por trás da igreja, o homem pensou em si e no irmão. Viu como seus caminhos haviam sido sempre tão diferentes e como nunca chegariam realmente a se encontrar. E ele disse: - Deus, o que eu faço para esquecer o meu irmão?" (França Júnior, 1976: 131).

\section{“FILHOS TRISTES” \& O VIÚVO}

Com relação ao conto "Filhos tristes", o que se percebe de imediato é a reiteração das expressões "filhos tristes", "filhos pequenos e magros" e "saudades". 0 narrador, em primeira pessoa, faz um rearranjo das frases, de modo a enfatizar sempre a tristeza que the desperta ao ver os filhos "pequenos e magros". E eles são "tristes". E é por isso que o narrador sente "saudades", pois lança para o futuro a inevitável certeza de que, quando adultos, seus filhos deixarão de ser filhos, para se transformar em "amigos e companheiros". 
0 conto guarda, assim, uma estreita relação com o primeiro romance do autor, 0 viúvo, visto que registra a preocupação de um pai com seus filhos pequenos, magros e tristes. Tal é a mesma idéia que norteia o romance - a tristeza e o medo da personagem, o Sr. Pedro, que, ao perder a esposa, sentese apreensivo com a responsabilidade de educar seus filhos, um casal de gêmeos, Ronaldo e Tânia, e que ainda não completaram um ano de idade. A tristeza e a magreza de Ronaldo, assim como se vê no conto, são evidentes em vários momentos: "Chamei o pequeno, e ele olhou para mim com uma expressão que me preocupou. Um olhar triste e de pessoa que se sente sozinha" (França Júnior, 1965: 62). A menina é mais expansiva e gosta das brincadeiras do pai, ao passo que o menino é mais arredio: "Fiquei brincando com ela e ele levantou-se e, apanhando o travesseiro que havia caído, encostou-se na cadeira e ficou nos olhando. E outra vez voltou o seu olhar triste de quem está se sentindo sozinho" (França Júnior, 1965: 62).

Decorridos cinqüenta dias do falecimento da esposa, o Sr. Pedro continua sem querer voltar à vida normal. Seus filhos estão na casa dos avós maternos e ele sente uma necessidade imperiosa de se ocupar o tempo todo, como uma forma de fugir da melancolia e da insônia. Passa a executar tarefas aparentemente sem importância, tais como lavar o carro à noite, ou conferir mercadorias às cinco da manhã, como uma forma de preencher o vazio de seu mundo, marcado pela falta da esposa. Para tentar preencher esse vazio, Pedro demonstra um apego excessivo pelos objetos que pertenciam à esposa e através dos quais tenta encadear as reminiscências que se vão aflorando em sua memória. "Resolvi abrir o guarda-roupa e passar em revista os vestidos da Darcy. (...) Abracei o capote de peles, que ela ganhou do Sr. Armando logo que ficamos noivos, e pareceu-me que abraçava a Darcy" (França Júnior, 1965:38). Nesse caso, os vestidos evocam a presença física da esposa, pois a imagem conservada na memória é revivida com a ajuda desse ato repetitivo de abraçar um fragmento que retém uma lembrança de alguém que se foi.

0 motivo de todo seu sofrimento, além da perda da esposa, é agravado por um outro fato, de relevante importância, que também merece ser analisado. Trata-se do episódio em que as crianças foram almoçar na casa dos avós e, no caminho, sofrem um acidente descrito como o "desastre com 0 


\section{EM TESE}

Belo Horizonte, v. 9, p. I-28I, dez. 2005

ônibus": "No dia em que os meninos bateram com os rostos no ferro que envolve o encosto da cadeira, no desastre do ônibus, eu não gostei de ficar a olhar para os seus rostos. (...) Só os olhinhos permaneceram vivos e sempre parecendo que não sabem que o resto está estragado" (França Júnior, 1965: 135).

Essa passagem, extremamente dolorosa para o Sr. Pedro, parece estabelecer uma dupla semelhança com o conto "0 erro", de As laranjas iguais. É interessante observar que, nesse conto, o narrador, também em primeira pessoa, fala de um espancamento sofrido pelos seus filhos. É inegável a semelhança, como se pode comprovar a seguir: "Quando cheguei em casa meus cinco pequenos filhos estavam com os rostos machucados. Haviam batido neles com pedaços de pau. Em seus rostos disformes os olhinhos mal apareciam. E eles não choravam, estavam quietos e juntos. Todos os cinco assustados a um canto" (França Júnior, 1985: 21). A atitude do narrador, em ambas as narrativas, parece ser a mesma: um misto de espanto, de ódio, de indecisão sobre o que fazer para aplacar a dor de seus filhos e um sentimento de intensa revolta.

0 estudo comparado desses contos e romances nos leva pois à constatação de que certos episódios, como a construção de uma represa, ou a encenação da violência, não conseguem sobrepujar alguns fatos cotidianos, na maioria das vezes, que contribuem e muito para imprimir verossimilhança e dinamismo às personagens simples e comuns, e ao mesmo tempo tão vivas e familiares de Oswaldo França Júnior - quer seja um irmão, um pai, um filho ou um vizinho. Além disso, França Júnior compõe suas narrativas de maneira a exibir exatamente o duplo, ora como tema, motivo, leitmotif, ora como um conto que se desdobra em romance ou se apresenta como a síntese deste. De acordo com os exemplos que acabamos de ver, verifica-se que um dos aspectos fundamentais, quando se trata do motivo do duplo é, sem dúvida, o da repetição. Na obra do autor mineiro, ela se apresenta de diversas maneiras: para reforçar uma temática, como a da violência, para realçar a gradação de sentido e para enfatizar uma narrativa que está sempre a se debruçar sobre si mesma, num processo intra e autotextual que resulta na contínua reelaboração de uma linguagem comum, mas única e original. 
ABSTRACT :

This essay presents an analysis of Oswaldo França Júnior's three short stories, considering them as genesis, or else, as synthesis of some of his novels. Our aim is to convey how these literary genres, under the author's perspective, work as a double matrix, emphasising an ongoing rewriting technique.

KEY WORDS: Oswaldo França Júnior, short stories, novels, double, rewriting.

\section{REFERÊNCIAS BIBLIOGRÁFICAS}

AGUIAR, Melânia Silva de. 0 novo realismo de França Júnior. Minas Gerais. Belo Horizonte, 17 jul. 1976. Suplemento Literário, p. 2.

CHEVALIER, Jean; GHEERBRANT, Alain. Dicionário de simbolos: mitos, sonhos, costumes, gestos, formas, figuras, cores, números. 2. ed. Trad. Vera da Costa Silva et al. Rio de Janeiro: José 0lympio, 1989.

DALLËNBACH, Lucien. Le récit spéculaire. Paris: Seuil, 1977.

FRANÇA JÚNIOR, Oswaldo. O viúvo. 4. ed. Rio de Janeiro: Nova Fronteira, 1990.

FRANÇA JÚNIOR, Oswaldo. Os dois irmãos. Rio de Janeiro: ROCCO, 1976.

FRANÇA JÚNIOR, Oswaldo. As laranjas iguais (contos). 2. ed. Rio de Janeiro: Nova Fronteira, 1996.

FRANÇA JÚNIOR, 0swaldo. No fundo das águas. Rio de Janeiro: Nova Fronteira, 1987.

KEHL, Maria Rita. Televisão e violência do imaginário. In: HAMBURGER, Esther; BUCCI, Eugênio (Org.). A TV aos 50 - Criticando a televisão brasileira no seu cinqüentenário. São Paulo: Editora Fundação Perseu Abramo, 2000. p. 133-151. 